\title{
Short communication: Detection of Mycobacterium avium subspecies paratuberculosis by polymerase chain reaction in bovine milk in Brazil
}

\author{
I. A. Carvalho, ${ }^{*}$ A. Silva Jr., $†$ V. E. B. Campos, ${ }^{*}$ and M. A. S. Moreira* ${ }^{* 1}$ \\ *Laboratório de Doenças Bacterianas, Departamento de Veterinária, and \\ †Laboratório de Infectologia Molecular Animal, Instituto de Biotecnologia Aplicada à Agropecuária (BIOAGRO), Universidade Federal de Viçosa, \\ Minas Gerais, 36570-000, Brasil
}

\begin{abstract}
Mycobacterium avium ssp. paratuberculosis (MAP) is the causative agent of paratuberculosis, or Johne's disease, a chronic granulomatous enteritis that affects all ruminants worldwide. Since the isolation of MAP from intestinal tissue of human patients bearing Crohn's disease, there has been a debate on the possibility of this agent playing a role in the etiology of Crohn's disease. Milk could be the potential vehicle for transmission to humans. Mycobacterium avium ssp. paratuberculosis has already been detected in milk samples worldwide. In Brazil, detection of MAP is uncommon; however, it has already been detected by bacterial isolation and serological test. The aim of this study was to investigate the presence of MAP, by PCR, in raw milk samples in the region of Viçosa, Minas Gerais State, Brazil. Of 222 milk samples evaluated, $8(3.6 \%)$ quarter milk samples amplified fragments of similar size to that expected of $626 \mathrm{bp}$. These fragments were cloned and sequenced. The genetic analysis revealed a 99\% identity match between the sequences obtained in this study and the insertion sequence IS900 deposited in the GenBank. In the analyzed milk samples, MAP DNA was detected, confirming its presence in dairy cattle in the region of Viçosa. This is the first report of MAP presence in raw milk samples in Brazil.
\end{abstract}

Key words: Mycobacterium avium subspecies paratuberculosis, insertion sequence IS900, polymerase chain reaction, Johne's disease

Mycobacterium avium ssp. paratuberculosis (MAP) is a gram-positive, acid-fast and facultative anaerobic, intracellular bacterium. It is a fastidious microorganism that requires the growth factor mycobactin $J$ for in vitro growth. It belongs to the Mycobacteriaceae family and under microscopy, usually forms small clusters (Collins, 2003). Similar to other mycobacteria, MAP has a thick cellular wall composed mainly of lipids, characterizing

Received October 20, 2008.

Accepted July 27, 2009.

${ }^{1}$ Corresponding author: masm@ufv.br its alcohol-acid-resistant property, hydrophobicity, and great resistance to chemical processes, such as water chlorination (Whan et al., 2001).

Some researchers have indicated a possible role of MAP in Crohn's disease (Collins, 1997; Hermon-Taylor, 2002; Grant, 2005; Feller et al., 2007), whereas others have expressed doubt on this association (Abubakar et al., 2007; Waddell et al., 2008). Mycobacterium avium ssp. paratuberculosis was detected by culture, PCR, and serological methods in tissue and blood samples obtained from human patients bearing Crohn's disease (Bull et al., 2003; Olsen et al., 2003; Naser et al., 2004; Sechi et al., 2005). It is worth mentioning that Crohn's patients had already been treated successfully using drugs against MAP (Hermon-Taylor, 2002; Borody et al., 2007). However, some studies have shown that the etiology of Crohn's disease can involve a variety of viral and bacterial agents, including MAP, or an immunological origin. Evidence points to an interaction between a persistent environmental stimulus, such as a microbial antigen, and genetic factors that regulate an immunological response or a mucosal intestinal function (Shanahan and O'Mahony, 2005). The vehicle for transmission of MAP from animals to humans would be milk, but the causal association between MAP and Crohn's disease remains unclear.

Several studies reported survival of MAP in cows' milk after pasteurization; however, there is no agreement on the concentration of this bacteria present in the raw milk that can be effectively inactivated by the current pasteurization procedures (Chiodini and Hermon-Taylor, 1993; Millar et al., 1996; Ayele et al., 2005; Ellingson et al., 2005).

Currently, Brazil is the sixth-largest producer of milk worldwide, with a volume corresponding to approximately $4.5 \%$ of the world's production. The southeast region of the country is the largest producer, accounting for $38.4 \%$ of the whole domestic production, whereas the State of Minas Gerais contributes $27.9 \%$ of the dairy production in the country (IBGE, 2006).

Considering the socio-economical and public-health significance of milk quality in Brazil, this study was 


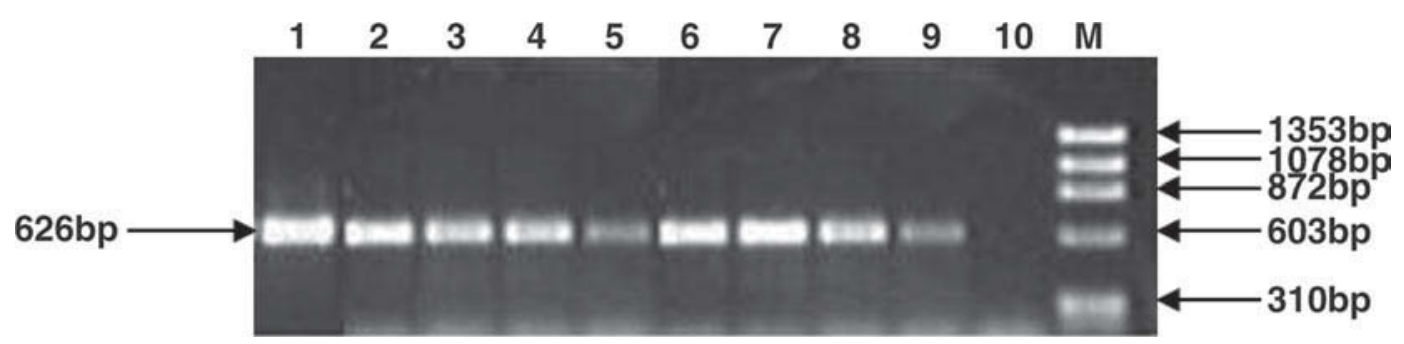

Figure 1. Polymerase chain reaction products visualized in $1 \%$ agarose gel electrophoresis using primer pairs BN1/BN2. Lanes 1, 2, 3, 4, 5, 6,7 , and 8 are amplified samples. Lane 9 is the positive control, 10 the negative control (Milli-Q water), and M the molecular marker ( $\varphi$ X174/ HaeIII, Promega, Madison, WI).

proposed to investigate the presence of MAP in the region of Viçosa, Minas Gerais State, Brazil.

Milk samples were collected from animals with clinical signs of paratuberculosis and from animals without clinical signs of the disease. Animals without overt paratuberculosis could have been subclinically infected and disseminating MAP to the environment via feces.

A total of 206 quarter milk samples were aseptically collected, and bulk tank milk samples from each of the 16 dairy herds in the region of Viçosa, Brazil, totaling 16 bulk tank milk samples, were collected. All the samples were processed according to the methodology described by Pillai and Jayarao (2002), and PCR was performed according to Sivakumar et al. (2005). A wild, certified MAP strain was used as the positive control, Milli-Q water was used as the negative control, and $\phi X 174 /$ HaeIII (Promega, Madison, WI) was used as the molecular marker. To confirm the identity of the amplified fragments (626 bp), the PCR amplified products were cloned in the pGEM vector using the pGEMT - Easy kit (Promega). Plasmid DNA was purified with Wizard Plus SV Minipreps DNA Purification System kit (Promega). Deoxyribonucleic acid sequencing, adapted by Sanger et al. (1977), was used to confirm the sequences in a MegaBACE 1000 (GE Healthcare, Buckinghamshire, UK) by using the M13 forward and reverse primers. The obtained sequences were edited by the DNA MAN software and compared with IS900 (Green et al., 1989) deposited in the GenBank under the accession number X16293.1 using the Basic Local Alignment Search Tool (BLAST) software, available at the National Center for Biotechnology Information Web site (http://www.ncbi.nlm.nih.gov).

Among 222 evaluated samples, 8 (3.6\%) amplified expected fragments of $626 \mathrm{bp}$ (Figure 1). All the positive samples were derived from the quarter milk. None of the bulk-tank samples amplified fragments according to the expected size. This fact can be explained by the dilution that happens in this kind of sample; therefore, bulk tank milk samples would not be ideal for MAP detection in the herd. Infected animals would not be diagnosed and could still be a source of infection to others.

Of these 8 amplified samples, one was collected from a young animal and the other $7(87.5 \%)$ from animals with 2 or more lactations that were between the age of 3 and $5 \mathrm{yr}$, when paratuberculosis affects cattle more frequently. Two (25\%) of the 8 samples of amplified DNA were degraded; thus, they were not used subsequently in the analysis. Four out of the 7 samples (6 quarter milk samples and the positive control) intended for the sequencing process were successfully sequenced. The genetic analysis showed a $99 \%$ identity match between the sequences obtained from the 4 quarter milk samples in this study and IS900.

The results confirmed the presence of MAP in the analyzed samples that showed identity with the insertion sequence IS900. This study confirmed MAP in the tested milk samples, providing key information about the presence of paratuberculosis in dairy herds in the region of Viçosa and in Minas Gerais State, Brazil. Because there is a lack of official paratuberculosis surveys and control programs in Brazil, further studies will be needed to support the adoption of national paratuberculosis control measures. This is the first report of MAP detected in raw milk samples from dairy cattle in Brazil.

\section{ACKNOWLEDGMENTS}

The authors thank both Marcos Jose Pereira Gomes, from Federal University of Rio Grande do Sul, Brazil, for providing a wild, certified MAP strain, and FAPEMIG (Fundação de Amparo à Pesquisa do Estado de Minas Gerais) for financing this study as part of the project (EDT-2412/05) "Detection of Mycobacterium avium subspecies paratuberculosis (MAP) by PCR in bovine raw milk samples."

\section{REFERENCES}

Abubakar, I., D. J. Myhill, A. R. Hart, I. R. Lake, I. Harvey, J. M. Rhodes, R. Robinson, A. J. Lobo, C. S. J. Probert, and P. R. 
Hunter. 2007. A case-control study of drinking water and dairy products in Crohn's Disease - Further investigation of the possible role of Mycobacterium avium paratuberculosis. Am. J. Epidemiol. 165:776-783.

Ayele, W. Y., P. Svastova, P. Roubal, M. Bartos, and I. Pavlik. 2005. Mycobacterium avium subspecies paratuberculosis cultured from locally and commercially pasteurized cow's milk in the Czech Republic. Appl. Environ. Microbiol. 71:1210-1214.

Borody, T. J., S. Bilkey, A. R. Wettstein, S. Leis, G. Pang, and S. Tye. 2007. Anti-mycobacterial therapy in Crohn's disease heals mucosa with longitudinal scars. Dig. Liver Dis. 39:438-444.

Bull, T. J., E. J. McMinn, K. Sidi-Boumedine, A. Skull, D. Durkin, P. Neild, G. Rhodes, R. Pickup, and J. Hermon-Taylor. 2003. Detection and verification of Mycobacterium avium subsp. paratuberculosis in fresh ileocolonic mucosal biopsy specimens from individuals with and without Crohn's disease. J. Clin. Microbiol. 41:2915-2923.

Chiodini, R. J., and J. Hermon-Taylor. 1993. The thermal resistance of Mycobacterium paratuberculosis in raw milk under conditions simulating pasteurization. J. Vet. Diagn. Invest. 5:629-631.

Collins, M. T. 1997. Mycobacterium paratuberculosis: A potential foodborne pathogen? J. Dairy Sci. 80:3445-3448.

Collins, M. T. 2003. Update on paratuberculosis: I. Epidemiology of Johne's disease and the biology of Mycobacterium paratuberculosis. Ir. Vet. J. 56:565-574.

Ellingson, J. L., J. L. Anderson, J. J. Koziczkowski, R. P. Radcliff, S. J. Sloan, S. E. Allen, and N. M. Sullivan. 2005. Detection of viable Mycobacterium avium subsp. paratuberculosis in retail pasteurized whole milk by two culture methods and PCR. J. Food Prot. 68:966-972.

Feller, M., K. Huwiler, R. Stephan, E. Altpeter, A. Shang, H. Furrer, G. E. Pfyffer, T. Jemmi, A. Baumgartner, and M. Egger. 2007. Mycobacterium avium subspecies paratuberculosis and Crohn's disease: A systematic review and meta-analysis. Lancet Infect. Dis. 7:607-613.

Grant, I. R. 2005. Zoonotic potential of Mycobacterium avium ssp. paratuberculosis: The current position. J. Appl. Microbiol. 98:1282-1293.

Green, E. P., M. L. Tizard, M. T. Moss, J. Thompson, D. J. Winterbourne, J. J. McFadden, and J. Hermon-Taylor. 1989 Sequence and characteristics of IS900, an insertion element identified in a human Crohn's disease isolate of Mycobacterium paratuberculosis. Nucleic Acids Res. 17:9063-9073.

Hermon-Taylor, J. 2002. Treatment with drugs active against Mycobacterium avium subspecies paratuberculosis can heal Crohn's disease: More evidence for a neglected public health tragedy. Dig. Liver Dis. 34:9-12.

IBGE (Instituto Brasileiro de Geografia e Estatística). 2006. Produção da Pecuária Municipal. http://www.cnpgl.embrapa.br/nova/ informacoes/estatisticas/producao_leite/index.php Accessed May $11,2006$.

Millar, D., J. Ford, J. Sanderson, S. Withey, M. Tizard, T. Doran, and J. Hermon-Taylor. 1996. IS900 PCR to detect Mycobacterium paratuberculosis in retail supplies of whole pasteurized cows' milk in England and Wales. Appl. Environ. Microbiol. 62:3446-3452.

Naser, S. A., G. Ghobrial, C. Romero, and J. F. Valentine. 2004 Culture of Mycobacterium avium subspecies paratuberculosis from the blood of patients with Crohn's disease. Lancet Infect. Dis. 364:1039-1044

Olsen, I., H. G. Wiker, E. Johnson, H. Langeggen, and L. J. Reitan. 2003. Elevated antibody responses in patients with Crohn's disease against MPP14, a $14 \mathrm{kDa}$ secreted protein purified from Mycobacterium avium subsp. paratuberculosis. Acta Vet. Scand. 44:287.

Pillai, S. R. and B. M. Jayarao. 2002. Application of IS900 PCR for detection of Mycobacterium avium subsp. paratuberculosis directly from raw milk. J. Dairy Sci. 85:1052-1057.

Sanger, F., S. Nicklen, and A. R. Coulson. 1977. DNA sequencing with chain-terminating inhibitors. Proc. Natl. Acad. Sci. USA 74:5463-5467.

Sechi, L. A., A. M. Scanu, P. Molicotti, S. Cannas, M. Mura, G. Dettori, G. Fadda, and S. Zanetti. 2005. Detection and isolation of Mycobacterium avium subspecies paratuberculosis from intestinal mucosal biopsies of patients with and without Crohn's disease in Sardinia. Am. J. Gastroenterol. 100:1529-1536.

Shanahan, F., and J. O' Mahony. 2005. The mycobacteria story in Crohn's disease. Am. J. Gastroenterol. 100:1537-1538.

Sivakumar, P., B. N. Tripathi, and N. Singh. 2005. Detection of Mycobacterium avium subsp. paratuberculosis in intestinal and lymph node tissues of water buffaloes (Bubalus bubalis) by PCR and bacterial culture. Vet. Microbiol. 108:263-270.

Waddell, L. A., A. Rajic, J. Sargeant, J. Harris, R. Amezcua, L. Downey, S. Read, and S. A. Mcewen. 2008. The zoonotic potential of Mycobacterium avium spp. paratuberculosis: A systematic review. Can. J. Public Health 99:145-155.

Whan, L. B., I. R. Grant, H. J. Ball, R. Scott, and M. T. Rowe. 2001. Bactericidal effect of chlorine on Mycobacterium paratuberculosis in drinking water. Lett. Appl. Microbiol. 33:227-231. 